\title{
Comparison of Cuminaldehyde Contents from Cell Suspension Cultures and Seeds of [Bunium persicum (Boiss.) B. Fedtsch.]
}

\author{
Sara KHOSRAVINIA ${ }^{\prime}$, Seyed Mahdi ZIARATNIA ${ }^{2 *}$, Abdolreza BAGHERI', \\ Ghadir RAJABZADEH ${ }^{2}$, Seyed Hassan MARASHI ${ }^{1}$ \\ ${ }^{1}$ Ferdowsi University of Mashhad, Department of Biotechnology and Plant Breeding, Mashhad, Iran \\ ${ }^{2}$ Research Institute of Food Science and Technology (RIFST), P.O. Box: 91735-139, km 12 Quchan \\ highway, Mashhad, Iran; m.ziaratnia@rifst.ac.ir (*correspondingauthor)
}

\begin{abstract}
The cell suspension culture and seed samples of Bunium persicum were extracted by supercritical fluid, hydrodistillation and solvent methods and analyzed by Gas Chromatography. In this study to compare the different methods of extractions, cuminaldehyde was targeted as one of the Black zira essential oil constitute. For callus induction the germinated seeds were cultured as explants on Murashige and Skoog medium supplemented with $2 \mathrm{mg} / \mathrm{l}$ 2,4-dichlorophenoxy acetic acid and $0.5 \mathrm{mg} / \mathrm{l}$ kinetin (treatment A) as well as $2 \mathrm{mg} / \mathrm{l}$ $\alpha$-naphthalene acetic acid and $0.5 \mathrm{mg} / \mathrm{l}$ 6-benzyl aminopurine (treatment B) and followed by cells suspension cultures establishment for the first time. The results of cell culture showed that cells from treatment B have a growth rate higher than A. All extracts were dissolved in $1 \mathrm{ml}$ hexane and analyzed by Gas Chromatography. According to the Gas Chromatography analysis, cuminaldehyde was not detected in the supercritical fluid samples, while it was present in hydrodistillation and solvent extract. Cuminaldehyde percentage in cell and seed solvent extracts was $4.65 \%$ and $18.61 \%$ respectively. Gas Chromatography results also showed that no cuminaldehyde is present in media extracts, means no cuminaldehyde has been secreted into the medium.
\end{abstract}

Keywords: cuminaldehyde, gas chromotography, hydrodistillation, solvent, supercritical fluid extraction

\section{Introduction}

Plant cell cultures are an attractive alternative source to whole plant for production of high-value secondary metabolites (Ravishankar et al., 1999). There are numerous plant secondary metabolites with interesting biological activities which have found applications in pharmaceutical industries, cosmetics, biopesticides and agrochemicals, flavours or food additives, odours and fragrances, and natural pigments (Goossens et al., 2003). Several successful studies on commercial production of secondary metabolites by plant cell suspension cultures have been reported such as shikonin from Lithospermum erythrorbizon, berberine from Coptis japonica (Fujita, 1988) and taxol from Taxus species (Blechert and Guenard, 1990).

Black zira [Bunium persicum (Boiss.) B. Fedtsch.] (Zireh Irani, Zireh kuhi, Black cumin), is one of the important medicinal and aromatic plants in Iran that belongs to Apiaceae family. Black zira as a perennial herb grows in Northern areas of Khorasan, Kerman, East of Zagros to Bandar Abbas and South of Alborz in Iran. It is also distributed in central Asia, Pakistan, Afghanistan, Keshmir, and Pamir (Azizi, 2005). The seeds are consumed widely as a condiment. In an indigenous remedy, seeds are regarded as stimulants, carminatives and found to be useful in diarrhea and dyspepsia treatment (Foroumadi et al., 2002). In addition, the plant is used for culinary purposes, flavoring foods and beverages (Pourmortazavi et al., 2005). It is also reported that Black zira seeds contain essential oils (up to $7 \%$ ) rich in monoterpene aldehydes. The main constitutes of essential oils are cuminaldehyde, $p$-mentha-1,3-dien7-al and p-mentha-1,4-dien-7-al (Thappa et al., 1991). Cuminaldehyde, 4-isopropylbenzaldehyde, is a natural organic compound with the molecular formula $\mathrm{C}_{10} \mathrm{H}_{12} \mathrm{O}$. It is a benzaldehyde with an isopropyl group substituted in the 4-position (Fig.1). It has a pleasant smell and contributes to the aroma of Apiaceae family oils. It is also used commercially in perfumes and other cosmetic products applied in skin areas likely to be exposed to sunshine, excluding rinse-off products (Foroumadi et al., 2002). In addition, it has inhibitory effect on tyrosinase (Parvez1 et al., 2007), toxic activity against Acantboscelides obtectus (Regnault-Roger and Hamraoui, 1995), suppressant melanin formation in cultured murine melanoma cells (Nitoda $e t$ al., 2008) and the most inhibition of $\beta$-carotene oxidation and lipid peroxidation (Sharififar et al., 2010).

In order to extract from cells suspension cultures different solvents including hexane (Brown and Charlwood, 1986), ethyl acetate (Yamada et al., 2002) and methanol (Ceoldo et al., 2009) were used. The extraction of essential oil components using solvent at high pressure, supercritical fluids, has received much attention in the past several 
50<smiles>CC(C)c1ccc(C=O)cc1</smiles>

\section{Cuminaldehyde}

Fig. 1. Chemical structures of cuminaldehyde

years, especially in food, pharmaceutical and cosmetic industries because of presenting an alternative to conventional processes such as organic solvent extraction and hydrodistillation (Assis and Lancas, 1999; Barnabas et al., 1994; Doraiswamy et al., 1999; Eikani et al., 1999; Fekete et al., 1996).

The aim of this research was callus induction and consequently for the first time, establishment of cell suspension culture of Black zira in order to compare the different extraction methods of essential oil from the cell and seed samples. For that purpose, the percentage of cuminaldehyde in extracts was targeted.

\section{Materials and methods}

\section{Plant materials and Callus induction}

The seeds of Black zira were collected from the experimental farm of Ferdowsi University of Mashhad (36 $16^{\prime}$ $\mathrm{N}$ and $\left.59^{\circ} 36^{\prime} \mathrm{E}\right)$, Iran. Seeds were washed in running tap water and then disinfected by immersion in $70 \%(\mathrm{v} / \mathrm{v})$ ethanol for $1 \mathrm{~min}$ followed by $30 \mathrm{~min}$ in $1 \%(\mathrm{v} / \mathrm{v})$ sodium hypochlorite for surface sterilization. To remove the adherent residue, seeds were finally rinsed with sterile distilled water for three times. Sterilized seeds were cultured on simple medium containing $0.5 \%$ sucrose and $0.7 \%$ agar for solidification. $\mathrm{pH}$ was adjusted on 5.8 using $1 \mathrm{~N} \mathrm{NaOH}$ or $1 \mathrm{~N} \mathrm{HCL}$ before autoclaving at $121^{\circ} \mathrm{C}$ for $20 \mathrm{~min}$. All the cultures were incubated in the dark conditions at $4^{\circ} \mathrm{C}$ for 3 months.

The germinated seeds were cultured on MS medium (Murashige and Skoog, 1962) supplemented with 3\% sucrose, $2 \mathrm{mg} / 1$ 2,4-D and $0.5 \mathrm{mg} / \mathrm{l}$ Kin (treatment A) and 2 $\mathrm{mg} / \mathrm{lNAA}$ and $0.5 \mathrm{mg} / \mathrm{l} \mathrm{BA}$ (treatment $\mathrm{B}$ ) and $0.7 \%$ agar. Cultures were incubated at $23 \pm 2{ }^{\circ} \mathrm{C}$ in dark conditions for callus induction. Calli were subcultured in a similar medium at 4-week intervals.

\section{Chemicals}

Kinetin (Sigma-Aldrich, Milano, Italy), 6-benzyl aminopurine (Sigma-Aldrich, Milano, Italy), $\alpha$-naphthalene acetic acid (Merck, Darmstadt, Germany) and 2,4-dichlorophenoxy acetic acid (Merck, Darmstadt, Germany) were chemicals for callus induction and establishment of cell suspension cultures. Cuminaldehyde standard (Merck, Darmstadt, Germany) and hexane solvent (Merck, Darmstadt, Germany) were used for standardization and extraction respectively.

\section{Suspension cultures}

For establishment of cell suspension cultures, 25-dayold yellow callus (300 mg fresh weight) was inoculated into $100 \mathrm{ml}$ Erlenmeyer flasks containing $15 \mathrm{ml}$ MS liquid medium similar to that used for callus induction cultures. All cultures flask were then placed on a shaker $(120 \mathrm{rpm})$ at $23 \pm 2^{\circ} \mathrm{C}$ in dark conditions. The cells suspension cultures were subcultured every 7-10 days in $15 \mathrm{ml}$ of fresh medium for 6 months. After establishment of the cell cultures, to get the real suspension cultures, the cells were sieved with a $210 \mu \mathrm{m}$ sterile stainless steel filter (Fig. 2).

\section{Determination of the cell growth rate}

Determination of the rate of cell growth in terms of fresh weight and dry weight was carried out by harvesting weekly three replications in each treatment. The cells
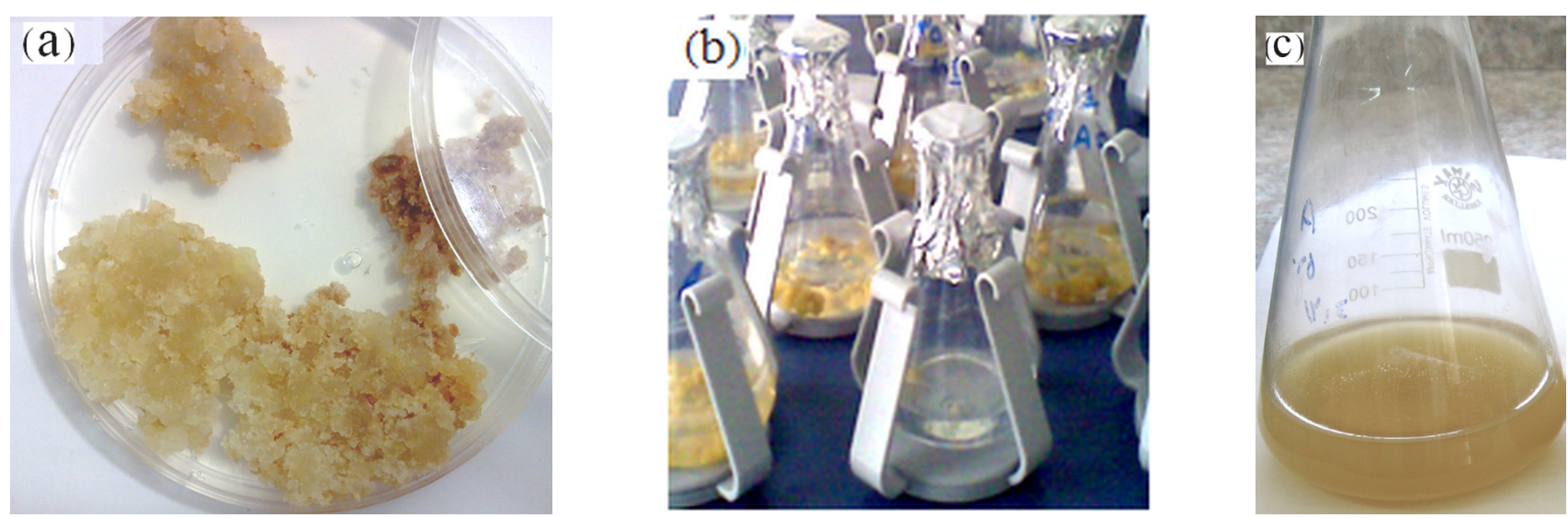

Fig. 2. Callus culture of Bunium persicum in MS solid medium, 3 month after inoculation (a) and Cell suspension cultures. Aggregative cells, 8 weeks after culture (b) and separated cells after sieve (c) 
were separated from medium through vacuum filtration using a pre-weighed filter paper (Whatman no. 4). The filtrated cells were washed three times with distilled water to remove medium components and then any excess water removed before fresh weight measurement. To measure the dry weight, cells were placed in an oven at $40{ }^{\circ} \mathrm{C}$ until constant weight and the dry cell weight was then calculated.

\section{Extraction of intracellular cuminaldehyde by solvent}

Hundred $\mathrm{g}$ of fresh cells of A and B treatments were dried in an oven at $40^{\circ} \mathrm{C}$. Dried cells of A and B and 2 g seeds as control were powdered in a mortar and pestle and consequently extracted in the presence of hexane. The filtrate extract was concentrated by rotary evaporated at $40^{\circ} \mathrm{C}$ and finally kept at $4{ }^{\circ} \mathrm{C}$ until use for Gas Chromatography analysis. The crude extract weight from A, B cells and seeds were $21.7 \mathrm{mg}, 24.2 \mathrm{mg}$ and $31 \mathrm{mg}$ respectively.

\section{Supercritical fluid extraction (SCF)}

In this study, $7 \mathrm{~g}$ of dried B cells and $2 \mathrm{~g}$ seeds were powdered and extracted with Supercritical $\mathrm{CO}_{2}$ under $200 \mathrm{~atm}$ pressure and $45^{\circ} \mathrm{C}$ temperature for $60 \mathrm{~min}$ static followed by 30 min dynamic (single run for each plant). A Dura flow manual variable restrictor $(\mathrm{Ki})$ was used in the SCF system to collect the extracted analytics. The supercritical $\mathrm{CO}_{2}$ flow rate through the Dura flow restrictor was approximately $3 \mathrm{ml} / \mathrm{min}$ (compressed). The extracted analytics were collected in a $30 \mathrm{ml}$ ethanol in a $50 \mathrm{ml}$ volumetric flask. Final extracts weight from B cells and seed were $27 \mathrm{mg}$ and $50 \mathrm{mg}$ respectively.

\section{Hydrodistillation}

The samples ( $50 \mathrm{~g}$ seed, $4 \mathrm{~g}$ and $6 \mathrm{~g}$ dried A and B cells respectively) were extracted by hydrodistillation system for $1.5 \mathrm{~h}$, using a Clevenger-type apparatus, according to the European Pharmacopoeia (1975). The volatile distillate was collected over anhydrous sodium sulphate and refrigerated until use for Gas Chromatography analysis. The yield of the seed oil was $2.9 \% \mathrm{v} / \mathrm{w}$ based on plant dry weight.

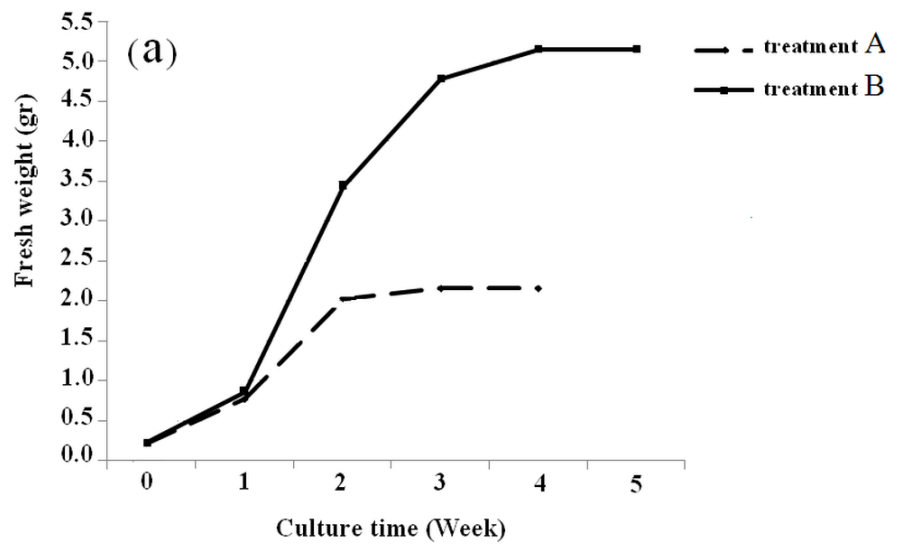

Determination of secretory cuminaldehyde

In order to determine the concentration of secreted cuminaldehyde into the media, $10 \mathrm{ml}$ filtrated medium culture of $\mathrm{A}$ and $\mathrm{B}$ treatments were freeze-dried. The dry weight for extracts from A and B medium was $18.5 \mathrm{mg}$ and $22.3 \mathrm{mg}$ respectively.

\section{Gas Chromatography (GC) Analysis}

For comparison of different extraction methods, cuminaldehyde was targeted as one of the Black zira essential oil and constitutes.

Gas Chromatography was performed on a Varian PU4500 chromatograph, with a FID and a CP Sil 5CB column $(30 \mathrm{~m} \times 0.25 \mathrm{~mm}$ i.d., $0.25 \mathrm{~mm}$ film thickness). The oven temperature was programmed from $80^{\circ} \mathrm{C}$ to $200^{\circ} \mathrm{C}$ at $8^{\circ} \mathrm{C} / \mathrm{min}$ and kept $20 \mathrm{~min}$ at $200^{\circ} \mathrm{C}$. The carrier gas was Ar with a flow rate of $1.1 \mathrm{ml} / \mathrm{min}$. Injector and detector temperature were set at $200^{\circ} \mathrm{C}$ and $205^{\circ} \mathrm{C}$ respectively. The injection volume for the seed samples and cuminaldehyde standard was $0.5 \mu \mathrm{l}$ and for the media and cell samples, 5 $\mu l$.

\section{Results and discussion}

\section{Effect of plant growth regulators on cell growth}

Bunium persicum callus cultures were derived from the germinated seeds on MS medium supplemented with two treatments, A ( $2 \mathrm{mg} / \mathrm{l} 2,4-\mathrm{D}$ and $0.5 \mathrm{mg} / \mathrm{l}$ Kinetin) and B $(2 \mathrm{mg} / \mathrm{l} \mathrm{NAA}$ and $0.5 \mathrm{mg} / \mathrm{l} \mathrm{BA})$, within 10-12 days of incubation in dark conditions. Yellow, friable and fresh callus were observed on both combinations. There are many reports for the successful application of different plant growth regulator combinations for callus induction and cell suspension cultures in several species by other researcher (Abenavoli et al., 2003; Ceoldo et al., 2009; Narayan et al., 2005). In this investigation the best growth of Bunium persicum callus was obtained on B treatment. However, other study indicated that callus of Black zira have a well growth on MS medium containing $2 \mathrm{mg} / \mathrm{lNAA}$ and 2 $\mathrm{mg} / \mathrm{l}$ Kin (Vlizadeh et al., 2006). Wakhlu (1990) recom-

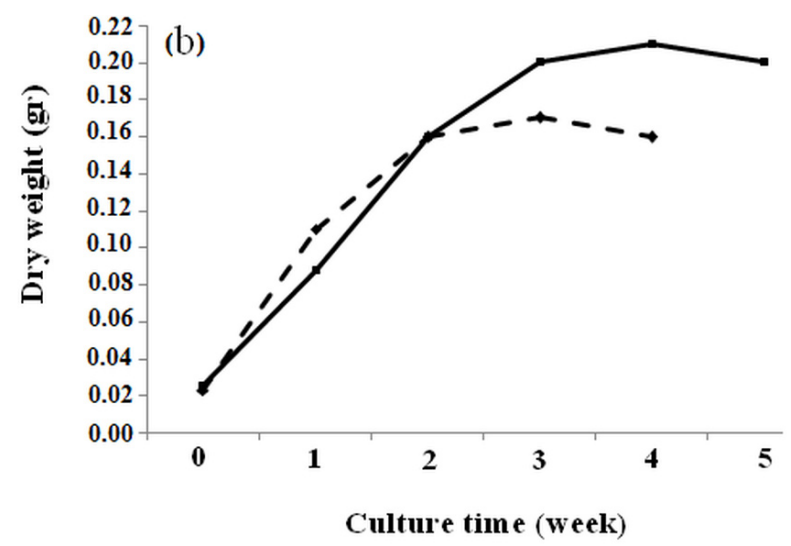

Fig. 3. Effect of different combinations of phytohormone on fresh (a) and dry (b) weight of cell from suspension cultures of Bunium persicum in a 5-week period in MS liquid medium. A ( $2 \mathrm{mg} / \mathrm{l} 2,4-\mathrm{D}$ and $0.5 \mathrm{mg} / 1$ Kinetin $)$ and B ( $2 \mathrm{mg} / 1 \mathrm{NAA}$ and $0.5 \mathrm{mg} / \mathrm{l} \mathrm{BA})$ 
52

mended the same medium but with hormonal combination (2 mg/l 2,4-D and $4 \mathrm{mg} / \mathrm{l} \mathrm{Kin).}$

Well-developed callus was used as an initial material for establishment of the cells suspension cultures which were grown on MS liquid medium similar to that used for callus induction cultures. The growth pattern of the cells in terms of fresh and dry weight in a 5-week period in both treatments of A and B were investigated (Fig. 3). The time course study on fresh and dry weight of the cells revealed that the biomass in treatment $\mathrm{A}$ increases up to 3 weeks while in case of treatment $B$, it happened up to 4 weeks. The maximum fresh and dry weight in treatment $\mathrm{A}(2.16$ $\mathrm{g}$ and $0.17 \mathrm{~g}$ respectively) was obtained after three weeks whereas in treatment $\mathrm{B}$ (5.16 g and $0.21 \mathrm{~g}$ respectively) occurred after four weeks. Thus treatment B promoted rapid growth of cells similar to callus cultures in solid medium.

\section{Effect of solvent extraction on concentration of cuminaldebyde}

According to GC chromatogram, the retention time of cuminaldehyde (standard) was obtained at $6.8 \mathrm{~min}$ (Fig. 4). The percentage of cuminaldehyde in hexane extracts from seed, A and B cell samples was found to be $18.61 \%, 4.63 \%$ and $4.73 \%$ respectively (Tab. 1 ). The cuminaldehyde content in the cells of both treatments (A and B) was almost equal and but in seeds it was 4 -fold more. Cuminaldehyde is known as one of the major constitute of seed essential oil of Black zira which possesses multiple biological activities (e.g. antifungal, antioxidant and anti-melanoma) (Nitoda et al., 2008; Shahsavari et al., 2008; Takayuki et al., 2007). Brown and Charlwood (1986) reported that in Pelargonium fragrans (Willd.), the undifferentiated callus accumulated negligible amounts of monoterpene components, whose numbers and concentrations of these components are more than what in parent plants.

Based on our GC results no cuminaldehyde was present in the hexane extract of treatments A and B media. It is therefore can be concluded that no cuminaldehyde even at low concentration has been excreted into the medium (Tab. 1).

Comparison of different extraction methods based on cuminaldehyde concentration in seed samples

By comparing the cuminaldehyde content in hydrodistillation and solvent extract, it was revealed that cuminaldehyde percentage in seed extracts were significantly different and was $58.87 \%$ and $18.61 \%$ respectively. It was also found that no cuminaldehyde is present in SCF extract of seeds (Tab. 1).

Obviously cuminaldehyde percentage as a target compound, in hydrodistillation was in much higher amount than solvent extraction samples and was also the major

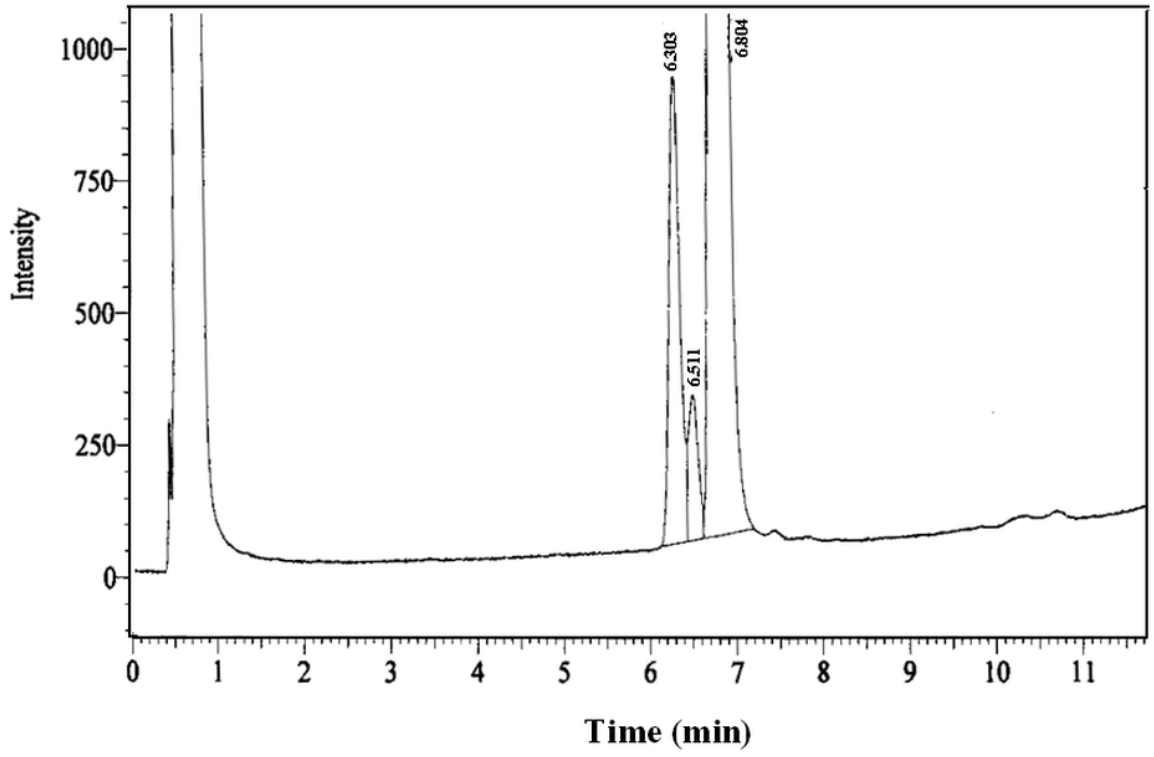

Fig. 4. GC chromatogram of the cuminaldehyde standard (Arrow shows the cuminaldehyde pick)

Tab. 1. Comparison of cuminaldehyde percentage in seed, cell suspension cultures and medium of Bunium persicum in three extraction methods

\begin{tabular}{|c|c|c|c|c|c|}
\hline \multirow{3}{*}{ Extraction Methods } & \multicolumn{5}{|c|}{ Samples } \\
\hline & \multirow{2}{*}{ Seed } & \multicolumn{2}{|c|}{ Cell Suspension Culture } & \multicolumn{2}{|c|}{ Medium } \\
\hline & & Treatment A & Treatment B & Treatment A & Treatment B \\
\hline Hexane & $18.61 \%$ & $4.63 \%$ & $4.73 \%$ & \multicolumn{2}{|c|}{ Not detected } \\
\hline Hydrodistillation & $58.87 \%$ & \multicolumn{2}{|c|}{ Not detected } & Not & ted \\
\hline Supercritical Fluid & Not detected & \multicolumn{2}{|c|}{ Not detected } & Not & ted \\
\hline
\end{tabular}


constituted in hydrodistillation samples. It means that the composition and even the concentration of constitutes of the extracts can be influenced by different extraction methods (Anklam et al., 1998; Azizi and Davareenejad, 2009; Mortazavi et al., 2010; Pourmortazavi et al., 2003, 2004; Salehi et al., 2008; Stashenko et al., 1996).

Pourmortazavi et al. (2005) have also compared the percentage of cuminaldehyde obtained from hydrodistillation and SCF. They reported that cuminaldehyde was detected in both extraction methods, though in SCF it was at lower level. In our results no cuminaldehyde was found in SCF extract. On the other hand the hydrodestillation- derived cuminaldehyde in our experiment was markedly higher than that reported by them in the same extraction method. These differences can be attributed to the harvest time and conditions, climatic and seasonal factors. Technical differences can also be a reason for obtaining different results, for example static and dynamic times in SCF extraction in those two investigations were different. In reports of Agarwal et al. (1991) and Abduganiew et al. (1997), that black cumin seed were extracted with hydrodistillation, cuminaldehyde was also the major component.

\section{Conclusion}

In conclusion, the results of this study have shown that for production of more biomass, the treatment $\mathrm{B}$ is more suitable than A. It was also found that cells of treatment A are more susceptible to browning than cells of treatment B. Results also demonstrated, though hydrodistillation is a suitable method for extraction of cuminaldehyde from seeds, it is not favored for cell samples. According to the obtained results of this study for isolation of cuminaldehyde from cell samples, the hexane extract is recommended. The results have shown that two different hormonal treatments have no significant effect on cuminaldehyde content in cell samples of Bunium persicum.

\section{Acknowledgements}

The authors thank the Research Institute of Food Science and Technology (RIFST) for financial support.

\section{References}

Abduganiew BE, Abdullaev UA, Aripov KN, Baser KHC, Oezek T (1997). Composition of the essential oil of Bunium persicum (Boiss.) B. Fedtsch. from Tajikistan. J Essential Oil Research 9:597-598.

Abenavoli MR, Sorgona A, Sidari M, Badiani M, Amodio F (2003). Coumarin inhibits the growth of carrot (Daucus carota L. cv. Saint Valery) cells in suspension culture. J Plant Physiol 160:227-237.

Agarwal SG, Ghosh S, Jamwal PS, Raina AK, Thappa RK (1991). Comparative studies on the major volatiles of kala zira (Bunium persicum seed) of wild and cultivated sources. J
Food Chemistry 41:129-134.

Anklam E, Berg H, Mathiasson I, Shrman M, Ulberth F (1998). Supercritical fluid extraction (SCF) in food analysis: A review. J Food Additives and Contamination 15:729-750.

Assis LM, Lancas FM (1999). High-resolution gas chromatography and high-resolution gas chromatography/mass spectrometry study of the volatile fraction obtained from highinertinite Brazilian coal by supercritical fluid extraction. J Micro Column Separations 11:501-512.

Azizi M (2005). Bunium persicum essential oils suppressed potato sprouting in storage. In: Proceedings of the $36^{\text {th }}$ International Symposium on Essential Oils. Budapest, Hungary, PP. 78-820.

Azizi M, Davareenejad GH (2009). Essential oil content and constituents of Black zira (Bunium persicum [Boiss.] B. Fedtsch.) from Iran during field cultivation (domestication). J Essential Oil Research 21:1-5.

Barnabas IJ, Dean JR, Owen SP (1994). Supercritical fluid extraction of analyses from environmental samples. J Analyst 119:2381-2394.

Blechert S, Guenard D (1990). Taxus alkaloids, 195-238 p. In: Brossi A (Ed.). The Alkaloids. Academic Press, San Diego.

Brown JT, Charlwood BV (1986). The accumulation of essential oils by tissue cultures of Pelargonium fragrans (Willd.). J Federation of European Biochemical Societies 204:117-120.

Ceoldo S, Toffali K, Mantovani S, Baldan G, Levi M, Guzzo F (2009). Metabolomics of Daucus carota cultured cell lines under stressing conditions reveals interactions between phenolic compounds. J Plant Science 176:553-565.

Doraiswamy LK, Ferreira SRS, Meireles MAA, Nikolov ZL, Petenate AJ (1999). Supercritical fluid extraction of Black pepper (Piper nigrun L.) essential oil. J Supercritical Fluids 14:235-245.

Eikani MH, Goodarznia I, Mirza M (1999). Supercritical carbon dioxide extraction of cumin seeds (Cuminum cyminum L.). J Flavour and Fragrance 4:29-31.

Fekete J, Kery A, Lemberkovics E, Oszagyan M, Sawinsky J, Simandi B (1996). Supercritical fluid extraction of volatile compounds from lavender and thyme. J Flavor and Fragrance 11:157-165.

Foroumadi A, Asadipour A, Arabpour F, Amanzadeh Y (2002). Composition of the essential oil of Bunium persicum (Boiss.) B. Fedtsch. from Iran. J Essential Oil Research 14:161-162.

Fujita Y (1988). Industrial production of shikonin and berberine, 228-235 p. In: Bock G, Marsh J (Eds.). Application of Plant Cell and Tissue Culture. Wiley, Chichester, UK.

Goossens A, Ha kinen ST, Laakso I, Seppa nen-Laakso T, Biondi S, De Sutter V, Lammertyn F, Nuutila AM, So derlund H, Zabeau M, Inze D, Oksman-Caldentey KM (2003). A functional genomics approach toward the understanding of secondary metabolism in plant cells. J plant biology 100:8595-8600.

Maisonneune S, Saint-Ruffine A (1975). European Pharmaco- 
54

poeia. 3.

Mortazavi SV, Eikani MH, Mirzaei H, Jafari M, Golmohammad F (2010). Extraction of essential oil from Bunium persicum Boiss. using superheated water. J Food and Bioproducts Processing 88:222-226.

Murashige T, Skoog F (1962). A revised medium for rapid growth and bioassay with tobacco tissue culture. J Physiol Plant 15:473-497.

Narayan MS, Thimmaraju R, Bhagyalakshmi N (2005). Interplay of growth regulators during solid-state and liquid-state batch cultivation of anthocyanin producing cell line of Daucus carota. J Process Biochemistry 40:351-358.

Nitoda T, D Fan M, Kubo I (2008). Effects of cuminaldehyde on melanoma cells. J Phytotherapy research 22:809-813.

Parvez1 S, Kang M, Chung HS, Bae H (2007). Naturally occurring tyrosinase inhibitors: mechanism and applications in skin health, cosmetics and agriculture industries. J Phytotherapy research 21:805-816.

Pourmortazavi SM, Sefidkon F, Hosseini SG (2003). Supercritical carbon dioxide extraction of essential oils from Perovskia atriplicifolia Benth. J Agricultural and Food Chemistry 51:5414-5419.

Pourmortazavi SM, Baghaee P, Mirhosseini M (2004). Extraction of volatile compounds from Juniperus communis L. leaves with supercritical fluid carbon dioxide: comparison with hydrodistillation. J Flavour Fragr 5:417-420.

Pourmortazavi SM, Ghandiri M, Hajimirsadeghi SS (2005). Supercritical fluid extraction of volatile components from Bunium persicum Boiss. (Black cumin) and Mespilus germanica L. (Medlar) seeds. J Food Composition and Analysis 18:439-446.

Ravishankar GA, Bhyalakshmi N, Ramachandra Rao S (1999). Production of food additives, 89-110 p. In: Ramawat KG, Merillon JM (Eds.). Biotechnology: Secondary Metabolites. New Delhi, Oxford IBH.

Regnault-Roger C, Hamraoui A (1995). Fumigant toxic activity and reproductive inhibition induced by monoterpenes on Acanthoscelides obtectus (Say) (Coleoptera), a bruchid of Kidney Bean (Phaseolus vulgaris L.). J Srored Prod Research 31:291-299.
Salehi P, Mohammadi F, Asghari B (2008). Seed essential oil analysis of Bunium persicum by hydrodistillation-headspace solvent microextraction. J Chemistry of Natural Compounds 44:111-113.

Shahsavari N, Barzegar M, Sahari MA, Naghdibadi H (2008). Antioxidant activity and chemical characterization of essential oil of Bunium persicum. J Plant Foods Hum Nutr 63:183-188

Sharififar F, Yassa N, Mozaffarian V (2010). Bioactivity of major components from the seeds of Bunium Persicum (Boiss.) Fedtch. J Pharm Sci 23:300-304.

Stashenko EE, Puertas MA, Combariza MY (1996). Volatile secondary metabolites from Spilanthes americana obtained by simultaneous steam distillation-solvent extraction and supercritical fluid extraction. J Chromatography 752:223232.

Takayuki S, Mami S, Azizi M, Yoshiharu F (2007). Antifungal effects of volatile compounds from Black zira (Bunium persicum) and Other Spices and Herbs. J Chem Ecol 33:21232132.

Thappa RK, Ghosh S, Agarwal SG, Raina AK, Jamwal PS (1991). Comparative studies on the major volatiles of Kala zira (Bunium persicum seed) of wild and cultivated sources. J Food Chemistry 41:129-134.

Vlizadeh M, Safarnejad A, Nematzadeh GA, Kazemitabar SK (2006). Regeneration of plantlets from embryo explants of Bunium persicum (Boiss.) B. Fedtsch. J Crop Science 1:9396.

Wakhlu AK, Nagari S, Barna KS (1990). Somatic embryogensis and plant regeneration from callus cultures of Bunium persicum Bioss. J Plant Cell Reports 9:137-138.

Yamada J, Fujita K, Sakai K (2002). Feedback regulation of $\beta$-thujaplicin production and formation of its methyl ether in a suspension culture of Cupressus lusitanica. J Phytochemistry 60:447-450. 